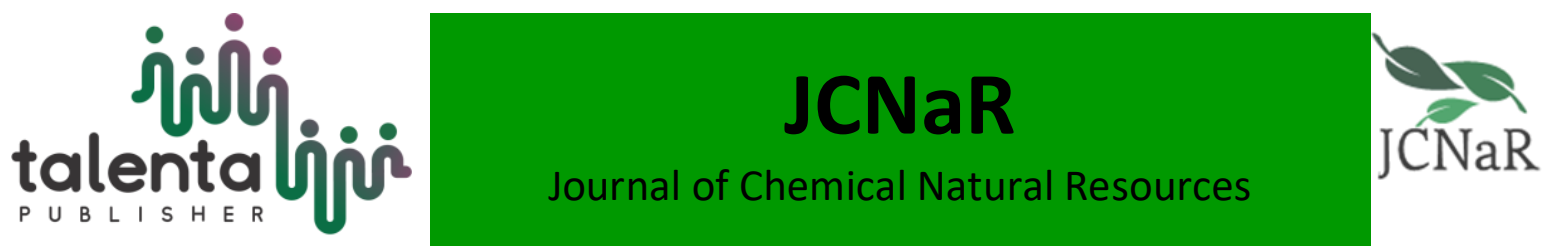

\title{
Gel Formulation of Ethyl Acetate Garlic Extraction and Its Activity Against Staphylococcus Epidermis
}

\author{
Khairan Khairan ${ }^{1}$, Yulia Astuti ${ }^{2}$, Irma Sari First ${ }^{3}$ \\ ${ }^{1,2,3}$ Department of Pharmacy, Faculty of Mathematics and Natural Sciences, University of Syiah Kuala, \\ Darussalam, Banda Aceh, Indonesia, 23111
}

\begin{abstract}
Garlic is known to have antibacterial and antifungal activities. This research aims to formulate the gel materials extracted from the garlic and to investigate the antimicrobial activities to Staphylococcus epidermidis. The phytochemical screening showed that the gel materials of ethyl acetate consisted alkaloid, flavonoid, and saponin substances. The formulation of gel was synthesized with different variations of 1,5 , and $10 \%$. In this research, the gel materials were analyzed to understand the stability, homogeneity, $\mathrm{pH}$, viscosity and dispersive powers. The results showed that good abilities of gel based on the taste, aroma and consistency, while the homogeneity property of each samples is influenced by the presence of gel concentration. The viscosity property of gels accounted for 3201.021664.04 Cps with $2.95-3.8 \mathrm{~cm}$ of dispersive powers. The ability of antimicrobial showed that higher concentration of $5 \%$ and $10 \%$ gels showed greater inhibitory zones of 18,10 and $22,08 \mathrm{~mm}$ compared to $1 \%$ of concentration.
\end{abstract}

Keyword: Garlic, Gel Formulation, Staphylococcus epidermidis

Received 30 July 2019 | Revised 26 August 2019 | Accepted 29 August 2019

\section{Introduction}

Garlic as one of plants has been widely used as medicinal plants. The extraction of garlic has been used to many medical treatments including as agents for antithrombotic, hypolipidemic, hypoglycemia, antiarthritic, antivirus, anticancer, antinematodal, and antimicrobial (Winarto, 2004). The biological activities of garlic are known to be occurred as the secondary metabolic composition and organosulphuric compounds are presented within garlic. Despite the presence of allicin which has been reported for the cause to the garlic's aroma and flavor, the others organosulphuric compounds could be found in garlic including alliin, diallyl disulfide, diallyl sulfide, diallyl trisulfide, ajoene, and vinyldithiin (Block, E. 2010).

One of the dermatitis occurred in human face is acne. The causes of acne could have been affected by several factors, and those are including the increasing of sebum productivity leading to the inclining numbers of colonial bacteria, sealing the pilosebase unit to produce

\footnotetext{
*Corresponding author at: Department of Pharmacy, Faculty of Mathematics and Natural Sciences, University of Syiah Kuala, Banda Aceh and Indonesia

E-mail address: khairankhairan@unsyiah.ac.id
} 
inflammation. There are many species of bacteria which can be the causes of acne in facial area such as Propionibacterium acne, Staphylococcus epidermidis, and Staphylococcus aureus (Djuanda et al., 1999). Bakht et al., in 2011, has reported that some amounts of ethyl acetate extracted from garlic were able to prevent the growth of Staphylococcus aureus, while same study has reported that $200 \mathrm{mg} / \mathrm{ml}$ of water and methanol extraction of garlic was able to prevent the growth zones of the bacteria within 20,0 and $23,0 \mathrm{~mm}$.

The form of extract is not the only phase that could be used as the antimicrobial materials. It has been reported that the extract of ethyl acetate from garlic in form of gel, cream and ointment could be used as the agents of antibacterial. Small percentage of methanol extraction from garlic have been successfully reported the growth of Staphylococcus aureus and Propionibacterium acne within 12-13 mm, and 10 to $11 \mathrm{~mm}$ respectively (Priyanka et al., 2014). Based on this brief explanation, given that that the gel formulation of ethyl acetate extraction of garlic was able to prevent the growth of bacteria-caused dermatitis, a research is conducted to formulate the gel within small 1, 5 and $10 \%$ concentration in preventing the growth of Staphylococcus epidermidis.

\section{Research Methodologies}

\subsection{Materials}

In this research, materials used were garlic (Allium sativum Linn), triethanoalamine (TEA), nutrient media, Muller-Hinton Agar (MHA), methanol, ethyl acetate, ethanol 70\%, nipasol, nipagin, carbopol, glycerin, ferrite chloride $10 \%$, hydrochloric acid $0.5 \mathrm{M}$ and $2 \mathrm{~N}$. The amounts of bacteria of Staphylococcus epidermidis were isolated form the laboratory of microbiology of Medical Faculty of Universitas Indonesia, Jakarta. The amounts of garlic were supplied by local market, and the samples have been analyzed at Center of Biology Research, Indonesia Institute of Science (LIPI), Bogor, Indonesia.

\subsection{Gels samples preparations}

\section{A. $\quad$ The preparation of samples}

The first step in preparing the samples is 2 kilograms of garlic were peeled to remove the skin. Afterward, the samples were immersed and washed with some water to be cleaned. The samples then were dried within room temperature for four weeks to produce garlic simplicia.

\subsection{The extraction of ethyl acetate from garlic}

The simplicia samples of garlic were prepared for 250 gram. These amounts of samples were homogenized with $140 \mathrm{ml}$ distilled water by using blender with maximum stirring for 10 minutes. In addition to reach enzymatic reaction, the homogenate materials were then allowed to stand for two minutes, so that it can be saturated with some amounts of saline solution $(\mathrm{NaCl}$ $0.9 \%$ ). Then the solution was extracted by using ethyl acetated solvent in separating funnel with 
ratio v/v. The extract of ethyl acetate obtained was then placed in rotary evaporator vacuum with $40 \mathrm{oC}$ to obtain the evaporated-extract of ethyl acetate. These amounts of extract were placed in temperature of $-20 \mathrm{oC}$ (Block E. 2010).

\section{A. Gels formulation from the extracts of ethyl acetate}

The process of gel formulation was started by preparing the compositions of each material. The process involves the exact compositions of carbopol, triethanoalamine, glycerin, nipagin, nipasol, and distilled water, while the extract samples were added with $1 \%, 5 \%$, and $10 \%$, and control gel without the addition of extracts which were indicated as F1, F2, F3, and F0 respectively.

The gel formulation was conducted by mixing method. $100 \mathrm{ml}$ of distilled water was heated before being placed inside a mortar. Afterward, 1 kilogram of carbopol was poured inside a mortar with some water. To obtain the homogenous phase, the samples were stirred by using pestle before being added with $1 \mathrm{ml}$ of triethanolamine (TEA) in gradual drops. Then, the extracts of ethyl acetate with different concentrations, the dissolved of $0,12 \mathrm{~g}$ nipagin in water solution, and dissolved $0.02 \mathrm{~g}$ nipasol in $2 \mathrm{~g}$ of glycerin.

Next, the homogenous solutions were added with the others materials in order while the stirring process was still be doing continuously. The materials were to be added orderly were the ethyl acetate, nipagin, nipasol dissolved within glycerin, and the control samples were composed without the addition of ethyl acetate extracts.

\subsection{Characterizations}

\section{A. $\quad$ The stability test}

In this study, the stability test was conducted according to the method issued by the National Health Surveillance Agency (2005). The samples were monitored throughout two different temperatures, which were $45 \pm 2 \mathrm{oC}$ as the high temperature for 24 hours and $-5 \pm 2 \mathrm{oC}$ as the low temperature for 24 hours, which was considered first cycle. This process was conducted at the exact treatments for 6 cycles in addition to investigate the change of colors, odors, and consistency.

\section{B. Homogeneity test}

We performed the homogeneity test according to the Indonesian National Agency of Drug and Food Control (2000). The test was performed by using organoleptic method in form of visual observation of upper, middle, and bottom sites of the amounts of gel which was dropped-layout on the surface of transparent glass after. The homogenous property was determined on the presence of amounts rough particles observed after 24 hours being composed. 
C. $\quad$ pH test

As many as $1 \mathrm{~g}$ gel was placed inside $10 \mathrm{ml}$ of distilled water. This solution was stirred by magnetic bar with constant stirring. After being stirred, the solution was stored for two hours for being tested by $\mathrm{pH}$ meter instrumentation. The measuring of $\mathrm{pH}$ was repeated for three times within 24 hours (Guleri, et al., 2013).

\section{Viscosity measurement}

The viscosity measurement was conducted by performing the Brookfield Viscometer. The samples were prepared by placing inside the instrument, and the spindle part of instrument was immersed to the sample. The viscosity property was measured by using spindle no. 6 with 20 rpm stirring (Reckitt, 2011).

\section{E. $\quad$ Dispersive powers measurement}

Samples were placed on the round-shaped glass within certain diameters. Then, the samples prepared were loaded with $150 \mathrm{~g}$ for 60 seconds, so that the samples were distributed. The diameter of samples that have been on the glass was measured by using ruler (Garg. 2002).

\section{F. Antibacterial test}

The antibacterial test was performed by using agar diffusion method. The suspension of bacteria of Staphylococcus epidermidis was prepared to be measured the density according to the McFarland standard. An amount of $150 \mathrm{ml}$ of Muller-Hilnon Agar (MHA) was added by the bacteria, so that this sample could be mixed. Then the mixing suspension was placed onto petri dishes for $20 \mathrm{ml}$ respectively, and then the samples were allowed to solidify. Inside the media, the a piece of disc paper which contains gentamycin as positive control, ethyl acetate as negative control, and gel formula onto the each media. Afterward, each of the petri dishes was turn over and incubated within $37 \mathrm{oC}$. In the next 48 hours, the inhibitor zones produced by bacteria were measured based on the diameter using millimeter calipers.

\section{Results and Discussion}

\subsection{Preliminary test of phytochemical of extract ethyl acetate}

The ethyl acetate extract produced from this study was $35.43 \mathrm{~g}$ with yield percentage accounted for $7.08 \%$. The physical characteristics based on organoleptic observation were brownyellowish color with a thick texture and a distinctive garlic odor. The extract of ethyl acetate from garlic aims to determine the secondary metabolites content which are contained in the extract of garlic. The phytochemical test results of ethyl acetate extracts can be seen by Table 1 below.

According to Table 1 above, the results showed that the extract of ethyl acetate from garlic contains alkaloids, flavonoids, and saponins constituents. The constituents obtained showed similar results which have been reported by Garla et al., (20130, suggesting the presence of alkaloids, flavonoids, and saponins from the water and ethanol extraction of garlic. 
Table 1. Active constituents obtained from the preliminary phytochemical test

\begin{tabular}{lllc}
\hline Constituents & \multicolumn{1}{c}{ Reactant } & \multicolumn{1}{c}{ Products } & Results \\
\hline Alkaloids & Dragedorf & Formed into yellow color & - \\
& Mayer & Formed cream color of precipitation & + \\
& Wagner & Formed brown color of precipitation & + \\
Flavonoids & $\mathrm{Mg}$ powder & Formed color & + \\
Saponins & $\mathrm{H}_{2} \mathrm{O}, \mathrm{HCl}$ & Formed foam without color & + \\
Tannins & $\mathrm{FeCl}_{2}$ & Formed orange color & - \\
\hline
\end{tabular}

\subsection{Evaluation test of gel of ethyl acetate extracted from garlic}

Compared to cream and ointment preparations, the decision of gel preparation was made because of the several advantages that can be obtained. Voight (1994) reported that the use of gel formulations provide more convenient situation as the gel could give cold experience in longer period, which also does not prevent the functional of hair on the skin, and give difficulties in washing the skin after using the gels. In this study, the evaluation test was conducted in order to understand the stability, homogeneity, $\mathrm{pH}$, viscosity and dispersive powers of the gels. The following Table 2 displays the results of evaluation of the gels.

The stability test was performed to understand the changes in odor, color, and consistency of the samples. According to the results, the samples showed no experience of changing in terms of odor, color and consistency either before or after being stored. The $1 \%$ gel preparation produced a yellowish white gel and transparent shape, while the 5\% gel preparation displayed a transparent yellow gel, and the $10 \%$ gel preparation produced a brown gel preparation with a distinctive garlic odor. Each of gel preparation colors comparatively is displayed in Figure 1.

From the results of the homogeneity test, the higher concentration of ethyl acetated influenced the homogenous particles as well as the $\mathrm{pH}$ level. The homogeneity test results showed that the $10 \%$ (F3) gel preparation produced non-homogeneous preparations because this was occurred due to high concentration of the extracts, implying to the higher $\mathrm{pH}$ level. According to Titaley et al., (2014), the acidity and base of gel preparations would have caused irritation and dryness to the skin, so that the gel preparations must be within the $\mathrm{pH}$ range of the skin. The $1 \%$ of concentration gel showed transparent with white-yellowish color without the presence of garlic odor, while the $5 \%$ concentration of the sample had the similar characteristics to the $1 \%$ which was white transparent physical property without garlic distinctive aroma. 
Table 2. Evaluation test results of ethyl acetate gels extracted from Garlic

\begin{tabular}{cccccc}
\hline No & Test results & $\mathbf{F}_{\mathbf{0}}$ & $\mathbf{F}_{\mathbf{1}}$ & $\mathbf{F}_{\mathbf{2}}$ & $\mathbf{F}_{\mathbf{3}}$ \\
\hline 1 & $\begin{array}{c}\text { Stability Test } \\
\text { • Odor (1-6 } \\
\text { cycles })\end{array}$ & No Changes & No Changes & No Changes & No Changes \\
$\begin{array}{c}\text { - Color }(1-6 \\
\text { cycles })\end{array}$ & No Changes & No Changes & No Changes & No Changes \\
$\begin{array}{c}\text { - Consistency } \\
(1-6 \text { cycles })\end{array}$ & No Changes & No Changes & No Changes & No Changes \\
& & & &
\end{tabular}

2. Homogeneity

Test

- Homogeneity homogeneous homogeneous homogeneous Non-

homogeneous

3. pH Test $(4.5$ to

6.5)

- Before cycling

4.78

4.90

5.32

5.78

test

4.71

4.83

5.27

5.69

test

4. Viscosity Test

(Range criteria:

2000-4000 Cps)

- Before cycling

3907.30

2870.03

2643.35

2301.69

test

- After cycling

3210.03

1087.05

1730.26

1603.03

test

5 Dispersive

Powers Test

(Criteria: $5-7 \mathrm{~cm}$ )

- Before cycling

test

2.80

3.65

3.80

3.50

- After cycling

2.95

3.70

4.25

3.80

test

In addition to obtain well-approved gel formulation, viscosity is one of the most important factors as it determines the distribution of the gel on the surface. Gels with good viscosity are capable to hold active substances which dispersed into the gel itself, and the value of viscosity also influences the consistency depending on the 1 (Madan and Singh, 2010). From the table 2, it can be seen that before the cycling test, the viscosity value decreased with the higher addition of 
extract concentration. Although the number was decreasing, the level of viscosity was still in the range of criteria of accepted gel formulation, which accounted for 2000-4000 cps. Meanwhile, after the cycling test was conducted, the viscosity level of each samples decreased into the outside range of the criteria except the control basis, accounted for $3210,03 \mathrm{cps}$.

The dispersive powers test was conducted to investigate the diameter of dispersion on the skin. The results showed that the dispersive powers of gel extracts were less than $5 \mathrm{~cm}$ either before or after the cycling test. According to the Garg et al., (2002), the acceptable dispersive powers of a good gel was in between 5 and $7 \mathrm{~cm}$. The decreasing dispersive powers of the samples was suspected due to the increasing of molecular sizes after being dissolved by the solvent, so that the amounts of aqueous matters were in captive decreasing the dispersive powers. Despite of this explanation, the decreasing of dispersive powers is also indicated by the high number of viscosity level of gel formulation (Shintaingsih, 2007).

\subsection{Antibacterial activities test results}

The antibacterial test was conducted by performing the agar diffusion method with the use of gentamicin as the positive control, and the ethyl acetate extracts gel as the sample. The Staphylococcus epidermidis is the bacteria that cause inflammation in facial area, leading to the emergence of acnes and boils (Radji, 2011). The results of antibacterial test showed that the $1 \%$ concentration of gel extracts of ethyl acetate provided no observational bacterial activities, while the $5 \%$ and $10 \%$ concentration showed activities of antibacterial observed from the inhibitor zones. Respectively, each samples had diameters of zones accounted for 18,01 mm and $22,08 \mathrm{~mm}$ which were categorized as strong and very strong. Compared to the positive control of gentamicin antibiotics, the diameters of inhibitory zones to Staphylococcus epidermidis was $28,92 \mathrm{~mm}$. The following Figure 1 showed the photographic images of the samples.

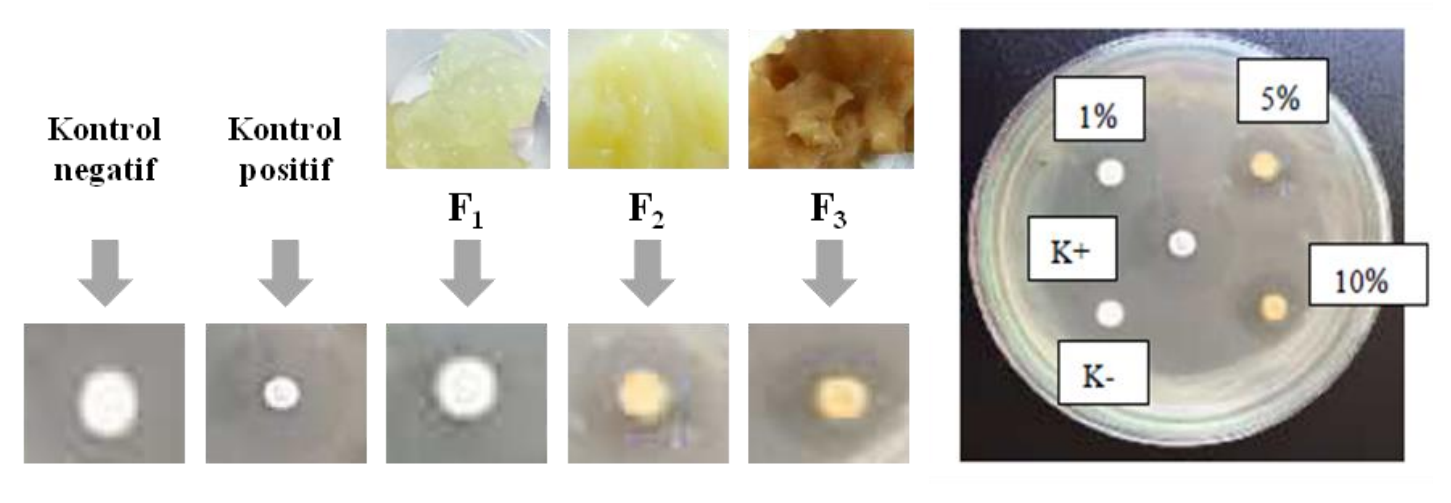

Figure 1. Photographic images of antimicrobial activities for each samples to the growth of Staphylococcus epidermidis

The antimicrobial activity of the extracts of garlic is always related to the presence of bioactive substances contained within the garlic (El-Mahmood and Amey, 2007). Phytochemical test showed that the ethyl acetate extracts from garlic contain alkaloids, flavonoids, and saponins. 
The alkaloids have capability in preventing the extrease enzymes, DNA and RNA polymerase of bacteria, which can also prevent the cell respiration (Aniszewki, 2007). Meanwhile, the flavonoids compounds have the ability to damage membrane cells of bacteria by denaturation the protein bonds, so that the bacteria's cells are not be able to reproduce due to the lysis leading to the cell-death (Rini and Mulyono, 2003). On the other hand, saponins are also able to disrupt the stability of bacteria's membrane cells which implies to instability within the surface tension of lysis cells (Cowan, 1999). With the presence of organosulphuric substances within the garlic, the antibacterial activities are enhancing, increasing the antimicrobial properties.

Table 3. The measurements of inhibitory zones of the gel extracts of garlic to Staphylococcus epidermidis

\begin{tabular}{|c|c|c|c|c|c|c|c|}
\hline \multirow[t]{2}{*}{ Samples } & \multicolumn{6}{|c|}{ Diameters of inhibitory zones (mm) } & \multirow[t]{2}{*}{ Intensity $^{\mathbf{a}}$} \\
\hline & $\mathbf{D}_{1}$ & $\mathbf{D}_{2}$ & $\mathbf{D}_{3}$ & $\mathbf{D}_{4}$ & $\mathbf{D}_{5}$ & $\Sigma \mathbf{D}$ & \\
\hline $\begin{array}{l}\text { Gentamisin } \\
\text { (control positive) }\end{array}$ & 29,00 & 29,10 & 28,50 & 29,00 & 29,00 & 28,92 & Very strong \\
\hline F0 (Basis gel) & 0 & 0 & 0 & 0 & 0 & 0 & - \\
\hline $\begin{array}{l}\text { F1 }(1 \% \text { of extracts } \\
\text { concentration }\end{array}$ & 0 & 0 & 0 & 0 & 0 & 0 & - \\
\hline $\begin{array}{l}\mathrm{F} 2 \text { (5\% of extracts } \\
\text { concentration) }\end{array}$ & 18,00 & 18,04 & 18,00 & 18,02 & 17,09 & 18,01 & Strong \\
\hline $\begin{array}{l}\text { F3 (10\% of extracts } \\
\text { concentration) }\end{array}$ & 22,00 & 22,04 & 21,09 & 22,01 & 22,03 & 22,08 & Very strong \\
\hline
\end{tabular}

Note: antensity dispersive powers of inhibitory zones (Morales et al., 2003.

According to Lawson et al., (1990), allicin is an organosulphuric substance contained within the garlic, which has antibacterial, antifungal, antioxidant, and anticancer abilities. Therefore, the antibacterial activities consisted within the gel formulation of ethyl acetate of garlic are suspected from the active substances such as alkaloids, flavonoids, saponins, and all organosulphuric compounds.

\section{Conclusions}

The extracts of ethyl acetated from garlic are able to be formulated in form of gel preparation. The lowest concentration of sample which is $1 \%$ has white-yellowish transparent color without distinctive aroma, in contrast the higher concentrations have different evaluation properties. For $5 \%$ concentration, the color is yellow transparent without garlic aroma, while the $10 \%$ concentration has distinctive garlic aroma with less transparent and brown color. The evaluation of tests result showed that the gel formulations tend to be stable and good homogenous, with skin-accepted level of $\mathrm{pH}$, while with the high value of viscosity provides small dispersive powers. Antibacterial activities test results suggest that the $1 \%$ concentration of extracts has no effects to the diameter of inhibitory zones, while $5 \%$ and $10 \%$ concentrations provide good and 
strong inhibitory zones to Staphylococcus epidermidis accounted for 18,01 mm and 22,08 $\mathrm{mm}$ of diameters respectively.

\section{References}

[1] Aniszewki, T., 2007, Alkaloid-Secrets of Life. Elsevier. Amsterdam, Netherland.

[2] Bakht, J., Tayyab, M., Ali, H., Islam, A., and Shafi, M., 2011, Effect of Different Solfent Extracted Sample of Allium sativum (Linn) on Bacteria an Fungi, African Journal of Biotechnology, 10(31): 5910-5915.

[3] Block E., 2010, Garlic and Other Alliums The Lore and The Science, The Royal Society of Chemistry, Cambridge, UK.

[4] Cowan, M.M. 1999. Plant Products as Antimicrobial Agents. Clin. Microbiol. Rev., 12 (4): 564-582.

[5] Ditjen. POM, Depkes RI., 2000, Parameter Standar Umum Ekstrak Tumbuhan Obat, Departemen Kesehatan Republik Indonesia, Jakarta.

[6] Djuanda, A., Hamzah, M. dan Aisah, S., 1999, Ilmu Penyakit Kulit dan Kelamin, Balai Penerbit Fakultas Kedokteran Universitas Indonesia, Jakarta.

[7] Garba, I., Umar, A.I., Abdulrahman, A.B., Tijjani, M.B., Aliyu, M.S., Zango, U.U. and Muhammad, A., 2013, Phytochemical and Antibakterial Properties of Garlic Extract, Bayero Journal of Pure and Applied Sciences, 6(2): 45 - 48.

[8] Garg, A., Anggarwal, D., Garg., S. Singla, A. K., 2002, Spreading of Semisolid, Formulation: an Update, Pharmaceutical Technology, September: 84-102.

[9] Guleri, K. T., and Preet, K. L., 2013, Formulation and Evaluation of Topical Gel of Aceclofenac. Journal of Drug Delivery and Therapeutics.

[10] Harbrone, J.B., 1987, Metode Fitokimia, Terjemahan dari Buku Phytochemical Methode. Padmawinata, K., dan Soediro., I. ITB. Bandung.

[11] Lawson, LD, De Graves, F, Tyler, J., 1990, HPLC Analysis of Allicin and Other Thiosulfonates in Garlic Cloves Homogenate, Planta Medica.

[12] Madan, J., \& Singh, R., 2010, Formulation and Evaluation of Aloevera Topical Gels, International Journal of Pharmacetical Sciences., 2 (2), 551-555.

[13] El-Mahmood, A.M. and Amey, J.M., 2007, Invitro Antibacterial Activity of Parkia Biglobosa (Jacq) Root Bark Extract Against some Microorganisms Associated with Urinary Infections, Afr. J. biotechnol, 6 (11): 1272-1275.

[14] Morales, G., Sierra, P., Mancilla, A., Paredes, A., Loyola, L.A., Gallardo, O., and Borquez, J. 2003. Secondary Metabolites From Four Medicinal Plants From Northern Chile: Antimicrobial Activity And Biotoxicity against Artemia salina, J. Chil. Chem. Soc., 48 (2): 13-18.

[15] National Health Surveillance Agency, 2005, Cosmetic Products Guide 1st Ed., Anvisa, Brazil.

[16] Priyanka, K. G., Khale, A., Srivastava, R., 2014, Invitro Assessment of Polyherbal Topical Gel Formulation Of Anti-Acne, Anti-Microbial and Antioxidant activity, Mumbay, India. 
[17] Radji, M., 2011, Buku Ajar Mikrobiologi Panduan Mahasiswa Farmasi dan Kedokteran, Penerbit Buku Kedokteran EGC, Jakarta.

[18] Reckitt Benckiser, 2011, Product Safety Data Sheet, Dettol Instant Hand Sanitiser, Version No. 11. p. 1-9.

[19] Rini, DM dan Mulyono, 2003, Khasiat dan Manfaat Daun Sirih (Obat Mujarab dari Masa Ke Masa), Agromedia Pustaka, Jakarta.

[20] Shintaningsih, L., 2007, Optimasi Komposisi Polysorbate 80 \& Cetyl Alkohol sebagai Emulsifying Agent dalam Lotion Virgin Coconut Oil dengan Aplikasi Desain Faktorial, Penerbit Universitas Sanatadharma Press., Yogyakarta.

[21] Titaley, S., Fatimawati, dan Lolo, W. A., 2014, Formulasi dan Uji Efektivitas, Sediaan Gel Ekstrak Etanol Daun Mangrove Api-Api (Avicennia marina) sebagai Antiseptik Tangan. Pharmacon, Jurnal Ilmiah Farmasi, 3 (2): 99-106.

[22] Voight, R., 1994, Buku Pelajaran Teknologi Farmasi, Penerjemah: Soendani, Noerono.S., Edisi ke-5, Universitas Gajah Mada Press., Yogyakarta

[23] Winarto, 2004, Memanfaatkan Tumbuhan Sayur untuk Mengatasi Aneka Penyakit, PT Agromedia Pustaka, Tanggerang. 